2 Gatrad AR, Read AP, Watson GH. Consanguinity and complex cardiac anomalies with situs ambiguus. Arch Dis Child 1984;59:242-5.

${ }^{3}$ Talwalkar VC. Caution on preventing neural tube defects (letter). Br Med J 1981;283:917.

4 Dhariwal HS. Leicestershire-decline in perinatal mortality. In: MacFadyen IR, MacVicar J, eds. Obstetric problems of the Asian community in Britain. London: Royal College of Obstetricians and Gynaecologists, 1982:101-7.

${ }^{5}$ Barnes R. Perinatal mortality and morbidity in Bradford. In: MacFadyen IR, MacVicar J, eds. Obstetric problems of the Asian community in Britain. London: Royal College of Obstetricians and Gynaecologists, 1982:81-7.

Correspondence to Dr P B Terry, Aberdeen Maternity Hospital, Aberdeen AB9 2ZD.

Received 11 June 1985

\title{
Birth size in Indian ethnic subgroups born in Britain
}

\author{
P CHETCUTI, S H SINHA, AND M I LEVENE \\ Neonatal Unit, Leicester University Medical School
}

\begin{abstract}
SUMmaRY Comparison in size at birth was made among Indian mothers of Hindu, Sikh, and Moslem origin living in Leicester and their infants, and white mothers and their infants. White infants were significantly heavier than infants from all Asian subgroups studied and had larger heads. Sikh babies were significantly longer and heavier than Moslem and Hindu babies, and in some respects were more comparable to white infants than their Indian peers. There were no important differences between the Moslem and Hindu babies.
\end{abstract}

Birthweight and other anthropometric measurements of newborn babies show considerable ethnic variation; ${ }^{1}$ infants of mothers of Asian origin are lighter and shorter than those of white mothers. ${ }^{2-4}$ Studies of variations in sizes at birth, however, have not taken into account the vast heterogeneity of ethnic groups comprising the Asian population. A recent study showed that there was no significant difference in birthweight between Moslem and white infants but that Hindu babies were significantly smaller. ${ }^{5}$ We report the differences in size among healthy infants born in Leicester to mothers from three Indian subgroups and compare the sizes of these infants with those of white infants.

\section{Methods}

Healthy postpartum mothers of Indian origin delivering full term healthy infants (38-41 weeks' gestation) at either the Leicester Royal Infirmary or the Leicester General Hospital were divided into one of three groups: Moslem, Hindu, and Sikh. They were matched for age (within five years) and parity, and 50 women were enrolled in each group.
A fourth group of 50 healthy white women was also matched for similar factors. Babies of diabetic mothers were excluded from the study. Maternal height and weight at booking were recorded, and measurements of postpartum triceps and mid-arm circumference were made with Harpenden skinfold calipers and a non-stretchable linen tape measure, respectively. The infants were weighed naked at birth to the nearest $10 \mathrm{~g}$ and crown heel length measured on a neonatometer to the nearest millimetre; the average of three measurements were recorded. Maximal occipitofrontal head circumference was recorded to the nearest millimetre. The infants' triceps and subscapular skinfold thicknesses and mid-arm circumferences were also measured, and ponderal index was calculated as an index of relative growth. ${ }^{6}$ Means and standard deviations were computed and comparisons of groups were made by the unpaired $t$ test. All maternal and neonatal measurements were made by one of two people (PC or SHS).

\section{Results}

White mothers were taller $(\mathrm{P}<0.001)$ and heavier $(\mathrm{P}<0.004)$ than all Indian mothers. They also showed increased mid-arm circumferences when compared with Hindu and Moslem mothers $(\mathrm{P}<0.001)$ but not compared with Sikh mothers. Significant differences in skinfold thicknesses were noted only between white and Moslem mothers $(\mathrm{P}<0.02)$. Sikh mothers were heavier $(\mathrm{P}<0.04)$ than Moslem or Hindu mothers and had increased mid-arm circumferences $(\mathrm{P}<0.04)$ and skinfold thicknesses $(\mathrm{P}<0 \cdot 04)$. There were no differences in maternal stature among the three Indian subgroups. No significant differences were noted between 
Table 1 Maternal data. Mean (SD) for four maternal measurements. Maternal height and weight refer to measurements at booking, and triceps thickness and mid-arm circumference were recorded immediately postpartum

\begin{tabular}{|c|c|c|c|c|}
\hline & $\begin{array}{l}\text { White mothers } \\
(n=50)\end{array}$ & $\begin{array}{l}\text { Sikh mothers } \\
(n=50)\end{array}$ & $\begin{array}{l}\text { Moslem mothers } \\
(n=50)\end{array}$ & $\begin{array}{l}\text { Hindu mothers } \\
(n=50)\end{array}$ \\
\hline Height (cm) & $162 \cdot 1(7 \cdot 23)$ & $156 \cdot 3(5 \cdot 4)$ & $155.0(5.62)$ & $154 \cdot 3(8 \cdot 24)$ \\
\hline Triceps thickness (mm) & $17 \cdot 1(5 \cdot 8)$ & $17 \cdot 7(5 \cdot 3)$ & $14 \cdot 4(5 \cdot 1)$ & $15 \cdot 5(4 \cdot 8)$ \\
\hline Mid-arm circumference $(\mathrm{cm})$ & $26 \cdot 1(2 \cdot 4)$ & $25 \cdot 4(2 \cdot 3)$ & $24.3(2 \cdot 7)$ & $24 \cdot 1(3 \cdot 1)$ \\
\hline
\end{tabular}

Table 2 Infant data. Mean (SD) for seven anthropometric measurements made during the first week of life

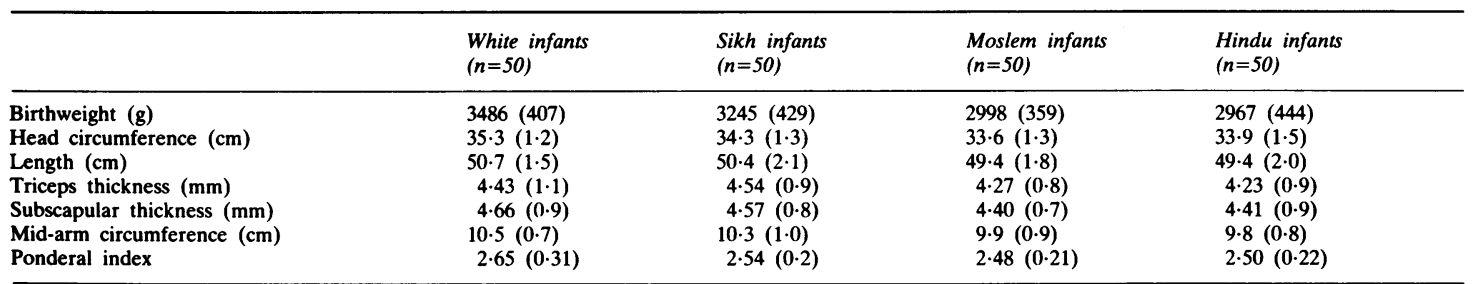

Moslem and Hindu mothers. Table 1 summarises the maternal data.

White babies were heavier than all Indian babies $(\mathrm{P}<0.005)$ and had larger heads $(\mathrm{P}<0 \cdot 001)$. They were longer than Hindu and Moslem babies $(\mathrm{P}<0.001)$, but there were no differences in length when compared with Sikh babies. Mid-arm circumferences were increased compared with Hindu and Moslem babies $(\mathrm{P}<0.001)$ but not compared with Sikh babies. Relative growth was better in white infants than in all Indian subgroups, as assessed by the ponderal index.

Sikh infants were longer $(\mathrm{P}<0.02)$, heavier $(P<0.004)$, and had greater mid-arm circumferences than Hindu and Moslem infants. Sikh infants had larger heads than Moslem infants $(\mathrm{P}<0.02)$, but no difference was noted when compared with Hindus. There was no difference in relative growth (ponderal index) among any Indian subgroup. A comparison between Hindu and Moslem babies showed no differences in any modality. Measurements of skinfold thicknesses showed no differences in any group of baby. Table 2 summarises this data.

\section{Discussion}

Our findings that Indian mothers and their newborn infants are lighter than white mothers and their babies agree with previous reports. ${ }^{23}$ Data from Birmingham showed that Pakistani babies born in Britain were larger than Indian babies born in Britain. ${ }^{4}$ We found that when considering Indian subgroups separately important trends were noted.
Sikh infants were longer and heavier than Moslem or Hindu infants, and no differences were noted in the size of Moslem and Hindu infants. A nutritional basis may explain this as Sikh mothers were heavier than Hindu or Moslem mothers and had increased mid-arm circumferences and skinfold thicknesses, both of which are indices of subcutaneous fat. Despite this we found no differences in the triceps or subscapular skinfold thickness among the babies from the Indian subgroups, though Sikh babies had increased mid-arm circumferences.

Dietary factors may account for these differences. Many Hindus are vegetarians, whereas Sikhs and Moslems eat meat traditionally. This does not, however, explain differences in size between Moslem and Sikh babies or the similarities between Moslem and Hindu babies. One study showed that during pregnancy Sikhs had the highest intake of most nutrients and ate a greater variety of foods compared with other Asian subgroups. ${ }^{7}$ In the Northwick Park study Moslem babies were significantly heavier than Hindu babies. ${ }^{5}$ Most Hindus were vegetarians, but the maternal energy and intake of protein in the two groups were within recommendations made by the Department of Health and Social Security.

Socioeconomic factors may also contribute to this regional variation. In Leicester most of the Asian population are in socioeconomic classes I to III (65\% of Hindus, $66 \%$ of Moslems, and $65 \%$ of Sikhs; Leicester Perinatal Mortality survey). This does not explain the anthropometric differences among the infants. The Asian mothers of the babies 
that we studied were born in either east Africa $(45 \%)$ or India $(45.5 \%)$. Only a few were born in Pakistan $(5 \%)$ or England (2\%). Less than one quarter of the Moslem mothers in our study were born in Pakistan, and $79 \%$ of Sikh mothers were born in India. The birth place of Hindu women were equally distributed between east Africa and India (Leicester Perinatal Mortality survey).

Our findings confirm the clinical impression that although Asians living in Britain are seen as one group, this population is far from homogenous, and the term Asian is imprecise for the purposes of clinical and epidemiological studies. Further regional studies are required to assess birth size among the Asian subgroups with an emphasis on socioeconomic and dietary factors.

We thank Miss E Mason and Professor M Clark for permission to use data from the Leicester Perinatal Mortality survey.

\section{References}

${ }^{1}$ Eveleth PB, Tanner JM. In: Worldwide variations in human growth. pp 228-412. Cambridge: Cambridge University Press, 1976:228-412.

2 Alvear J, Brooke OG. Fetal growth in different racial groups. Arch Dis Child 1978;53:27-32.

${ }^{3}$ Davies DP, Senior N, Cole G, Blass D, Simpson K. Size at birth of Asian and white Caucasian babies born in Leicester: implications for obstetric and paediatric practices. Early Hum Dev 1982;6:257-63.

${ }^{4}$ Clarson CL, Barker MJ, Marshall T, Wharton BA. Secular changes in birthweight of Asian babies born in Birmingham. Arch Dis Child 1982;57:867-71.

5 McFadyen IR, Campbell-Brown M, Abraham R, North WRS, Haines AP. Factors affecting birthweights in Hindus, Muslims and Europeans. Br J Obstet Gynaecol 1984;91:968-72.

${ }^{6}$ Lubchenco LO, Hansman C, Boyd E. Intrauterine growth in length and head circumference as estimated from live births at gestational ages from 26 to 42 weeks. Pediatrics 1961;37:403-8.

7 Wharton PA, Eaton PM, Wharton BA. Subethnic variation in the diets of Moslem, Sikh and Hindu pregnant women at Sorrento Maternity Hospital, Birmingham. Br $J$ Nutr 1984;52:469-76.

Correspondence to Dr M I Levene, Neonatal Unit, Department of Child Health, Leicester University Medical School, Leicester.

Received 24 April 1985

\title{
Acute hypothyroidism in a 3 year old
}

\author{
U MACFADYEN, B P O'MALLEY, AND P G F SWIFT \\ Departments of Child Health and Pharmacology, University of Leicester and the Department of Paediatrics, \\ Leicester Royal Infirmary
}

SUMMARY A 3 year old girl presented with a three week history of lethargy, constipation, and joint swelling. Investigation showed primary hypothyroidism associated with immunological changes including thyroglobulin antibodies. Reassessment several months after beginning thyroxine treatment confirmed persisting hypothyroidism. Primary hypothyroidism may present as a rapid onset disorder.

Primary hypothyroidism occurring in either children or adults is frequently autoimmune in origin arising from a chronic lymphocytic thyroiditis. ${ }^{12}$ It is also generally assumed that the development of symptomatic thyroid deficiency is a protracted process spanning months or even years ${ }^{3}$ which, in children, considerably affects growth and maturation. The acute development of primary hypothyroidism in a young child has not been described previously.

\section{Case report}

A girl aged 3 years 9 months born in England of non-consanguinous Asian parents presented with a three week history of lethargy and constipation. During this short period she had developed swelling of her hands and ankles and was reluctant to walk. She became increasingly tired, falling asleep at play school, and she refused her food. Bowel movements had become infrequent despite the use of laxatives and occasionally there were streaks of blood in her stool. In the two weeks before presentation her skin had become very dry. Bruising had developed over her knees, in the absence of any history of trauma. Perinatal, developmental, and previous medical histories were unremarkable. She was fully immunised. There was no family history of endocrine disorders.

On examination her height of $100 \mathrm{~cm}$ and weight of $11 \mathrm{~kg}$ were between the 75th and 95th centiles. She looked unwell with a pale puffy face. A moderate non-tender goitre was visible and palpable with no appreciable adenopathy. The skin was very dry and scaly particularly over the trunk and extensor aspects of her arms. There were several bruises over her knees. The proximal interphalangeal joints of the hands were swollen and there 